DE DE GRUYTER OPEN
Research Article

(C) 2018 Jozi Joseph Thwala and Mandla Alfred Twala. This is an open access article licensed under the Creative Commons Attribution-NonCommercial-NoDerivs License (http://creativecommons.org/licenses/by-nc-nd/3.0/).

\title{
An Investigation of Poetic Techniques from Stanzaic Forms to Fourteen-line Narratives in IsiZulu Poetry
}

\author{
Jozi Joseph Thwala \\ M.E.R Mathivha Centre for African Languages, Arts and Culture, \\ School of Human and Social Sciences, University of Venda, \\ Thohoyandou, Limpopo Province, South Africa
}

\author{
Mandla Alfred Twala \\ Director: Monitoring and Evaluation, \\ Gauteng Department of Infrastructure Development, \\ Johannesburg, Gauteng, South Africa
}

Doi: $10.2478 / \mathrm{mjss}-2018-0011$

\begin{abstract}
The objectives of this article are to survey and explicate the poetic techniques that are functional in stanzaic forms and fourteen-line narratives in isizulu. Various types of stanzas, namely: expanding, bulging, mixed, diminishing and regular are selected for analysis. The stanzaic forms start from four-line stanzas to fourteen-line narratives. Detailed discussions on the lines are the major focus of the article. Relevant examples are cited to display the stanzaic forms, types and sonnets. The differences among various sonnets are structurally highlighted to show the poetic techniques. The formalist approach is appropriate for this poetic discourse from the counting of lines, stanzas to fourteen-line narratives. Despite the poetic techniques that are fundamental in this analysis, the selected poems have a sound didactic principle that broaden human experiences, acquaint the reader with language proficiency and awaked new reality. They have artistic values that enhance coherence, social truth and descriptive imagery.
\end{abstract}

Keywords: Historic accomplishment, Intellectual cognition, Perception, Stanzaic organization, Structural approach and Topographical references.

\section{Introduction}

This is an arrangement of lines in a specific pattern that is characterised by words, ideas, rhythm and rhyme. Fletcher and Sceales (1969:148) define stanza as:

... a group of lines of verse arranged according to definite scheme under which the number of line, the metre and the rhyming pattern (where the poetry is rhymed) are regulated.

Ntuli (1984:17) postulates the arrangement of lines as follows:

A group of lines considered as a unit, forming a division of a poem, and recurring in the same pattern or variation of the pattern. A stanza pattern is determined by the number of lines, the kind of feet and the number of feet per line, and the rhyme scheme.

The lines are organized, positioned and co-ordinated to form a verse that is depicting a poetic 
meaning. The lines entail figures of speech and structural techniques that enhance poetic discourse. Abrams (1985:177) defines stanza as follows:

... is a grouping of the verse-lines in a poem, set off by a space in the printed text.

A stanza is a group of arranged and assembled lines in a poem that are considered to be a unit. Stanzas often function like paragraphs in prose. They are named according to the number of lines found in them. Their functions are to logically organize, develop and present the main ideas in a chronological, spatial or order of importance. The rationale of the study are to define, describe and outline the stanzaic forms that are used in isiZulu poetry in relation to a great variety of European stanza forms, namely: Rime royal, introduced by Chaucer, Ottavia rima, brought from Italian into English by Sir Thomas Wyatt and Spenserian Stanza, devised by Edmund Spenser. Their classification, arrangement and analysis provide a structural pattern that is fundamental in modern poetry.

Ntuli (1984:232-234) gives a theoretic understanding on types of stanzas that are prevalent in most isiZulu poetry, namely: regular, expanding, diminishing and bulging stanzas. Attenbernd and Lewis (1966:44) state the following about the stanzaic forms or verse paragraphs:

Lines are irregularly grouped so that the divisions correspond to important stages in the development of the narrative discussion.

Stanzaic forms or verse paragraphs are arrangement of thoughts in a poem that reflect the formulation, development and organization of the thesis statement. The ideas are logically arranged according to the introduction, body and conclusion.

\section{Research Methodology and Approaches}

There are presently many views that have emerged for determining the nature or essence of literary works. Selden (1985:54) describes these as follows:

These approaches concentrated on the formal features, manner of arranging language and the structure of content.

The scholar aims at determining what distinguishes 'literary' material from 'non-literary' material. The formalists approach was adopted to analyse the writer's technical prowess and craft skill (Selden 1985:7). The formalist believes that in any work of art such as poetry, the poet sometimes deliberately defamiliarises the raw material and objects of familiar actions and words that he uses to build up his poem. A poet can also defamiliarises his language by using what is called 'poetic devices'. Babbie and Mouton (2011) define data analysis as a process of bringing order, stricter and meaning of the collected data. The main purpose of data analysis in this article is to make general findings about stanzaic forms, types of stanzas and fourteen-line narratives.

Cuddon, (1984:657) defines a stanza as follows:

It may be of any number of well-crafted lines but more than twelve is uncommon...

Masuku, (1973:5-6) asserts this notion on stanzas:

English poetry has various types of stanzas which may be followed in African poetry as well. We have three, four, and five, six-line stanzas and so on. African poets should write definite stanzas in balanced form.

The stanzaic forms entail the types of stanzas, lines, metres and rhyme schemes. They are the structural elements that are significant for the determination of poetic units. 


\section{Deliberation on Stanzaic Forms}

Most poetic lines are acceptable if they are balanced. The state of balance is measured by a central idea that is stated through the use of a statement, extension, development and conclusion. An example of poetic balance is cited from the poem, Siyashweleza Nodumehlezi (Nodumehlezi Pardon us):
Sikhandene Nodumehlezi siyizinkumbi; Sikhandene siyashweleza siyizigidi;
(We are gathered in multitudes, Nodumehlezi, Nani matshitshi kaZulu huqani ibomvu, We are gathered in millions, requesting forgiveness, You Zulu maidens, besmear the red ochre, Hayan' ekaNomkhubulwane: shwele nkosi! Sing Nomkhubulwane's song: forgive us, king!) (Msimang 1990:3).

His praise-name is Nodumehlezi (He who is famous as he sits). This name was bestowed on him before he was enthroned. The significant role King Shaka played in Southern Africa is so remarkable that it is widely acclaimed. The poet states that the nation has gathered for forgiveness, admitting the irrational behaviour that has promoted evil from his death. Irrationality is seen when there is no tolerance between the individuals, groups, clans or parties. Stanzas are the marred divisions which are made in a poem in a regular way. We are aware that there are a variety of stanza patterns and forms. However, this study focused on the specific types that are prevalent in the selected sample. In each stanza we find a specific idea, rhythm as well as descriptive or evocative images. If the stanza is complete, its completeness is seen through all cognitive strategies; namely: repetition learning, expansion and organization. In this study the stanzaic forms are looked at from four to fourteen lines, as they appear in the poet's contributions. A brief historical background of the fourteen-lines poem, the sonnet, will be given and comparatively studied in the works of various well-known poets.

\subsection{Four-line Stanza}

The four-line stanza or quatrain is found in the poem Leso Sivakashi (That vistor):

\author{
Ekusondeleni kwakhe endlini, \\ Indlu yaqubuk' uhlevane, \\ lqhuqhiswa yilowo ngqoqwane, \\ Nomlilo eziko waqal' ukulotha. \\ (Msimang 1990:13).
}

(On his approach to the house,

The people's skin breaks out in a rash,

Shivering because of the frost,

Even the fire in the fire place started to die out.)

The stanza reveals the actions of the 'guest' as frost. Death is likened to a human 'guest' and dehumanized as the frost. What is elucidated in the stanza is different from what is revealed in the introductory and succeeding stanzas. It is obvious that the stanza has its own message that is put across through imagery and structural approach. The poet uses connotation to his own advantage. Using the word 'guest' for "death" is a purely subjective and a private connotation. The words, uhlevane (rash), ungqoqwane (frost) and umlilo eziko (fire in the fire-place) are recurrent images that represent specific actions, situations and ideas.

A second example of a four-line stanza is taken from the poem Amadwal' AseMhlathuze (The Mhlathuze's Rocks):

Nganishiya nisinge eMpumalanga, Mina muntu womhlaba obhadulayo Ngisinga enhla ngisinge ezansi, Ngibuye nisasinge eMpumalanga. (Msimang 1980:15).
(I left you gazing in the eastern direction

I, a bare-footed traveller

Looked upwards and downwards,

And came back still looking in an easterly directions.)

Repetition plays a major role in this stanza, especially the words -singa (to gaze at or to set eyes on) and eMpumalanga (in an easterly direction). The idea of comparison is highlighted in the stanza. The rocks of Mhlathuze are referred to as stable, rigid and long-standing creatures, while 
the poet regards himself as unstable, flexible and human with human qualities. The poet appeals to the sense of sight in this comparison.

\subsection{Five-line Stanza}

The five-line stanza or cinquain is highlighted in the poem, lqhwa (The frost):

Umuhle kunezihlabathi zolwandle,

(You are more beautiful than the sea sand,

Umhlophe kunobisi Iwezimazi zakwethu, You are more whiter than our milky cattle,

Wena nontandakubukwa ungesakabuli, ' You who likes to be seen to resemble a black-tailed finch,

Ngob' uqhwakela eziqongweni zezintaba, Because you sit on elevated mountain peaks,

Uzihlobise ngobakho ubumhlophe.

Beautifying yourself with your whiteness.)

(Msimang 1980:43).

This is a three-stanza poem which is divided into the following parts the following parts: an introductory stanza depicting beauty, emphasizing wena (you), referring to the frost; and the last stanza, which focuses on nami (I), referring to the poet. The quoted stanza highlights comparable beauty, whiteness, descriptive metaphor and spatial setting or topographical references.

The poet appeals to the sense of sight in both the imaginary and real world. His appeal is manifested in the poem on the educational figure $K u-D B Z N t u l i$ :

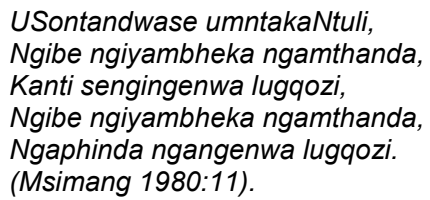

(He, who is envious of Ntuli,

I looked at him and adored him,

While I was injected by the inspiration,

I looked at him and adored him,

And again I got an injection of inspiration.)

The central ideas in this five-line stanza are those of honour, respect and the acquisition of inspiration. The mutual relationship between the poet and the educational figure portrayed in the poem is extolled. It is evident that the poet is envious of the educational figure. The educational figure has been a torch-bearer, not only to the poet, but also to the whole nation. His contribution to literary works is highly acclaimed and will remain a historic accomplishment forever. It is not only the poet himself who is injected with inspiration, as most African writers have benefitted from the adored figure. The educational figure's contribution reveals that he is always seeking to elevate, improve and direct people towards a socially acceptable life. It is noticeable that each stanza is rich in poetic images and multi-faceted associations, which all bring about the intended idea in a poetic manner. The idea is put forth both denotatively and connotatively towards a core theme.

\subsection{Six-line Stanza}

The six-line stanza or sestet example is cited from the poem, Siwela IMoretele (We are Crossing Moretele River):

Amacuban' eMoretele athenek' amandla nethemba,

Awagagamelanga okwamadlamb' oLwandle Olubomvu,

Awasithibelanga, azedlulela ejeqeza ebalisa,

Alila isililo sezililo nesilokazane,

Amafu phezulu ahlangana ehlukana,

Nelanga elalisihola laholekela emuva.

(The Moretele water lost power and hope,

It didn't chance upon the Red sea waves,

It didn't assume a stance for combat,

It grudgingly passed while glancing side by side,

It laments and sobs,

The clouds above converge and diverge,

Even the shining sun went back to darkness).

(Msimang 1990:15). 
The poet paints a scene of chaos that erupts, which is followed by bloodshed and lamentation. It is anthropomorphically stated that the river water lost its flowing power and hope. The verb, atheneka (they lost) is used as a pun called syllepsis. The well-selected words, amacubane (water) and amadlambi (waves) depict the meticulously use of connotative language to bring forth the intended poetic meaning of anarchy and obliteration. In case of the above example, the two words which are governed are amandla (power) and ithemba (hope). The natural imagery of river water, the Red Sea, clouds and the sun, portrays the scenery and express what has happened through poetic imagination.

The second example of a six-line stanza is taken from the praise-poem, Ku-DBZ Ntuli (In Honour of DBZ Ntuli):

Umthente ohlab' usamila.

Ithole likaMaShezi,

Elihlabe lingakamili nampondo,

Izizwe zonke zabuza,

Zathi kanti uBheki ungakanani.

(Msimang 1980:10).
(The coarse thorny grass pricks whilst still young.

The calf of MaShezi

That stabbed through without horns,

Because you emerged with Bheka,

All nations question how old Bheki is.)

In the stanza, the proverb, umthente ohlaba usamila means that a child shows his future charactter in childhood. Prof DBZ Ntuli is referred to as ithole likaMaShezi (the calf/son of MaShezi), that is, his mother. Bheka is the title of his first isiZulu novel, while Bheki is an abbreviation of his name Bhekinkosi (a person who is submissive to, and who believes and trusts in God). It is an informative stanza on the life, background and literary contribution of Ntuli.

\subsection{Seven-line Stanza}

The seven-line stanza or octave is sometimes called Rhyme Royal because it was the metre used in the Scottish court. The following example used is taken from the poem, Isibaya Esikhulu SeAfrika (Big Byre of Africa):

Ziyagiya ezimnyama,
Zigiye kwavuk' amathongo,
Yagiya yonkan' i-Afrika;
Omame bayakikizela,
Izintombi ziyagqashiya,
Izingane ziyagxumagxuma,
Halal' iyahalalis' i-Afrika!
(Msimang 1990:37)

Ziyagiya ezimnyama,

Zigiye kwavuk' amathongo,

Yagiya yonkan' i-Afrika;

Izintombi ziyagqashiya

Halal' iyahalalis' i-Afrika!

(Msimang 1990:37)
(The blacks are dancing,

They danced and the ancestors come to life,

The whole Africa danced;

The mothers are ululating,

The ladies frolic,

The children are hopping,

Hurrah! Applauds Africa!)

What is evident in the preceding stanza is the exhibition of distinctive rhythmic patterns in two or three word-groups. The poem depicts elation brought about by economic empowerment on the continent. The poem states that ecstasy is seen in all people, young and old, male and female. Indigenous culture couples happiness with dance, which is the source of aesthetic and spiritual life. Dance is rhythmical and rhythm is the essence of poetry. The performer uses the body: face, hands, arms, wrists, feet, thighs and head. Oratory is used as an art form when the performer commands, mimes and transmutes the images for creative potential and complex production.

The second seven-line stanza example is found in the poem, Inkondlo KaMkabayi (Mkabayi's Poem):

Ntombi zakwaZulu,

Ngivumiseni le ngoma;

Ntombi zikaMalandela,

Ngihayiseni le nkondlo;

Yinkondlo yomzwangedwa,

Yinkondlo kaMkabayi,

Yinkondlo kaLamula.

(Msimang 1990:32).
(Zulu ladies,

Let us sing this song;

Malandela ladies,

Let us recite this poem;

It is a poem on nostalgia,

It is Mkabayi's poem,

It is Lamula's poem.) 
Rhythm is brought about by a discontinuous, initial linking of words, 'ntombi (ladies); continuous initial linking yinkondlo (it is a poem) and the discontinuous figures Malandela, Mkabayi and Lamula as terminative linking words. It is extracted from a selected poem that expresses emotions, specific ideas and musical values. The poem as a whole has all the features of music, namely; pitch, tone, timbre, duration and tempo, which are so distinctive when the poem is sung. This poem attains its true fulfillment when it is recited, sung or performed. The poem is a tuneful piece which was composed with flavourful intellectual images for a historic and significant moment.

\section{Deliberation on Types of Stanzas}

The types of stanzas that have been selected for this article are regular, expanding, diminishing, bulging and mixed as they are cited in Ntuli and Ntuli (1988).

\subsection{Regular stanzas}

The poems have well-organized lines that form a stanza. The stanzas are made-up of equal lines and well-selected lexemes. This pattern is characterized by a concentrated content and mood of a poem that correspond with the essence of a theme. Its regularity comprises both rhythmic and rhyming sounds that help to enhance logic, rationale and correlation in the entire poem, Uvete Ewindini (A type of frog on the window). The poem comprises four stanzas that are systematically formed by equal lines.

\subsection{Expanding stanzaic pattern}

Ntuli (1984:234) gives the following explanation on expanding stanzaic pattern:

The significance of such an arrangement of lines is that the poet's ideas are expressed in order of importance and range towards a kind of climax.

The structure of the poem, Ngikuthandi Ukhona Lapho (I love you where you are) is characterized by irregular and unequal number of lines in various stanzas. They depict development of ideas, elaborate facts and increased number of lines. The first lines capture the reader's interest and imagination. The latter lines convey the message in a poetic form by enhancing imagery and descriptive language.

\subsection{Diminishing stanzaic pattern}

Ntuli (1984:234) remarks as follows:

The first stanza is the longest and the last one the shortest.

The poem entitled, Uban' Omubi? (Who is bad?), is structurally unique as it depicts the reduction of the number of words and exhibit a slanting pattern. Then introductory lines reveal setting, suspense and climax, while the concluding lines display denouement. The closing couplet, couched in perfect parallelism, reiterates the same idea in a colorful language.

\subsection{Bulging stanzaic pattern}

Ntuli (1984:234) contends that:

The middle stanzas have more lines than the first and the last portion of the poem.

The poem, Sengethembile (I am trusting), the stanzas are characterized by enlargement and expansion. They are artistically arranged to convey expectancy and anxiety. The increased number of lines are successfully communicating what the poet intends to convey. The poetic techniques 
that are outstanding in this selected poem are the following: a choice of relevant words and phrase, metaphoric use of language, linking words and logic ideas.

\subsection{Mixed stanzaic pattern}

The poems, Gatsheni, Uthanda Yiphi? (Which one does you like Gatsheni?), and Imbali Yehlungu (Flower of the newly burnt field) are made up of mixed stanzas which are guided by the volume of content, mood and actions. They are formed by variety, diverse and heterogeneous stanzaic patterns. They are combined and integrated to produce a hybrid called mixing stanza. Their features share the characters of the songs as special records of the times. They highlight spatial, historical and temporal settings. Their panegyric nature is exhibited in various stanzas. What are evident in both poems are stanzas of mixed lengths and miscellaneous structural pattern. They are, however, characterized by sarcasm, symbolism and sentiments that recreate sensory experiences.

\section{Results}

Scheffler (2015: 174) sees a stanza as follows:

A group of lines a poem that together form a unit. It creates the structure of a poem.

A couplet: A pair of successive lines of a poem (a rhyming couplet: two successive, rhyming lines of a poem).

A triplet: A three-line stanza or three line of a poem.

A quatrain: A four-line stanza or four lines of a poem.

A sestet: $A$ six-line stanza or six lines of a poem. It may also be the second section of a sonnet.

A heptastich: a seven-line stanza

An octave: An eight-line stanza. It may also be the first part of a sonnet.

It is discovered that there are few isiZulu poems that use couplets and triplets. The types of structural form that are commonly found are regular, expanding and mixed stanzas. The line or verse content follows the occurrence of statement, extension, development and conclusion of a stanza or paragraph is a character of traditional praise poetry. Modern poets like Msimang (1980) employs this type of construction in most stanzas as displayed in this extraction:

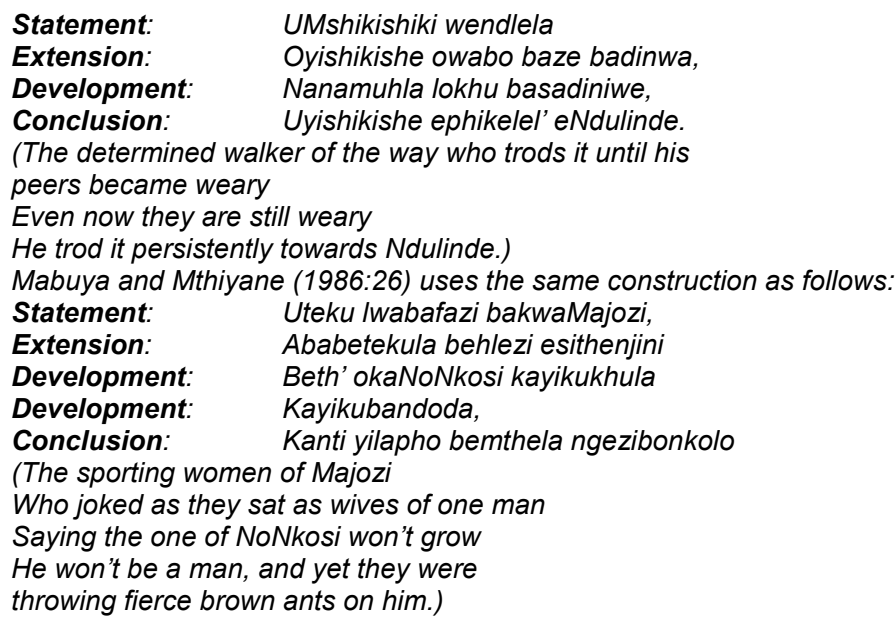

The above extract describes the influence of the traditional praises of King Shaka from Nyembezi (1978:20):

Uteku Iwabafazi bakwaNomgabhi,

Betekula behlez' emlovini, 


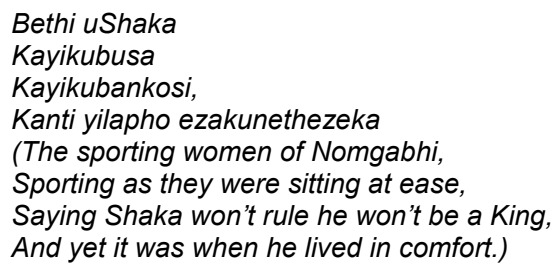

Form is a fundamental aspect in poetry. The word from has a board meaning as it is the organization of parts of a poem into a whole. Cuddon (1984:277) gives his assertion about the form as follows:

...The form of a literary work we refer to its shape and the manner in which it is made - as opposed to its substance or what it is about.

There are many types of form prevalent in poetry explication, but the well-known types are mental and physical forms. The physical form concentrates on the external shape of a poem. The aspects that are structurally looked at are the following: sounds, words, phrases and stanza forms.

It remains a challenge in indigenous languages to come-up with the specific and unique form of a sonnet without compromising the emotive language and poetic flavour. English sonnets serve as a point of departure for African language fourteen-line narratives.

\section{Deliberation on Forteen-Line Narrative or a Sonnet}

\subsection{Fourteen-line Narrative or A Sonnet}

Boulton,(1953:54) defines a sonnet as:

A poem of fourteen iambic pentameter lines with one of the following rhyme-schemes:

\begin{tabular}{|c|c|c|c|c|}
\hline Italian & abba & $\begin{array}{c}a b b a \\
\text { or } \\
\end{array}$ & cde & cde \\
& abba & abba & ccd & eed \\
Shakespearean & $a b a b$ & $c d c d$ & efef & gg \\
\hline
\end{tabular}

In the 16th century, there was also an outburst of sonnetering in France where the most notable sequences were by Du Bellay's L'olive in 1549. In Spain the sonnet was introduced by the Marquis de Santillana (1349-1458).

Cuddon (1984:642) has the following view about the sonnet:

The term derives from the Italian sonneto a 'little sound' or 'song'. It consists of fourteen lines, usually in iambic pentameters with considerable variations in rhyme scheme.

Initially, a sonnet was written for love. That assumption is no longer strictly confined to love, as before. The Italian Petrarchan (sonnet) originated in Italy in the thirteenth century. Lever $(1965: 3)$ has the following opinion:

It was the love poetry of Patriarch that shaped a new course for Western and European countries.

\subsection{Types of European sonnets}

English literature is dominated by two types of sonnets:

- The Italian form

- The English form. 


\subsubsection{Italian (Petrarchan) sonnet}

This type of sonnet developed from the Sicilian Strambotto. It consists of two quatrains and two tercets. The earliest sonnets were attributed to Giacomo de Lentino. Noted Italian lyric poets include Guinicelli, Vavalcantic and Dante. They usually used semi-Platonic and semi-religious devotion to the Lady or Donna. Patriarch established the sonnet as one of the major poetic forms. The Italian sonnet form is regarded as the basic or common form. The internal and external structure of the Italian sonnet can be summarized as follows:

- Fourteen poetic lines (an important requirement).

- It is divided into two parts; namely, octave and sestet.

- The octave with a fixed rhyme scheme characterized by two rhyming sounds, e.g. abba and abba.

- The sestet, on the other hand, does not have a fixed rhyme scheme. There may be two or three rhyming sounds, namely: cde and cde.

\subsubsection{English (Elizabethan) sonnets}

\subsubsection{Spenser}

Spenser deliberately weakens the capacity of his verse-form to suggest opposition, contrast and the arrangement of his facts. The structure of the Spenserian sonnet consists of three quatrains and a couplet, rhyming as follows: $a b a b, b c b c, c d c d$, ee.

\subsubsection{Shakespeare}

According to Swanepoel (1990:42), the experiment has succeeded within the wider framework of poetry, as it recalls an aesthetic experience. A couplet is a pair of consecutive lines of poetry of which the last words rhyme. Development takes place in the three quatrains. After the third quatrain a climax is reached, whereafter the turn commences. The rising line of thought is not concluded after line twelve but it is strikingly summarised in the rhyming couplet. The Shakespearean sonnet fell into three statements which were resolved in the final couplet and which had a clinching effect on the argument, often reversing the central idea expressed in the preceding lines. The Shakespearean sonnet consists of three quatrains followed by a couplet: abab, cdcd, efef, gg. In the Shakespearean and Spenserean sonnets, a different idea is expressed in each quatrain. The argument, theme and dialectic are tied up in the binding end couplet. Most Shakespearean sonnets consist of a love theme.

\subsubsection{Milton}

Milton's sonnet uses the Italian rhyme scheme. The internal unities are used with much freedom. He does not observe the division between the octave and the sestet. Milton follows the Italian (Petrarchan) sonnet which originated in Italy. Patriarch perfected the Italian sonnet by forming the octave that outlines the following rhyme: abbaabba and sestet that rhymed as follows: cdecde. The Miltonian sonnet, like the Petrarchan sonnet, does not rigidly follow the internal division into octave and sestet. Milton's sonnets received much attention in England.

\section{Discussion on Isizulu Sonnets}

Only one sonnet will be selected from each of the following Zulu poets: Vilakazi, Ntuli, Masuku and Msimang.

\subsection{BW Vilakazi's sonnet}

The first isiZulu sonnet is a translation from English language. It was written by Joseph Cotter, an 
American. Vilakazi rendered the sonnet into isiZulu during a period of translations, adaptations and transference of isolated lines and ideas. The sonnet is entitled Wena-ke Uyothini? (What shall you say?). The poem is composed of fourteen lines. The structure of this poem is different from those of Milton, Shakespeare, Wordsworth, Spenser and Italian sonnets. This poem does not follow any rhyme scheme. The translation conveys the sense, but not the whole structure of a poem. Perhaps Cotter's sonnet followed one of the known structural patterns of writing a sonnet, but Vilakazi's translation defuses it. The poem has striking images which are properly employed to put forth an idea of dissatisfaction. It is comparatively looked at in relation to the privileged and underprivileged, rulers and ruled as well as the economically empowered and economically disempowered.

\subsection{DBZ Ntuli's sonnet}

Ntuli's sonnet appears in his anothology called Imvunge Yemvelo (The Musical Sound of Nature). His sonnet is entitled Entwasahlobo (springtime). The one ingredient of beauty in poetry is form. Form implies some kind of definiteness or coherence and shape. Ntuli's poem qualifies as a sonnet because of prosodic elements and the physical form of octave and sestet. The poem is written in good isiZulu. It appears that Ntuli concentrates on both the mental and physical forms. Ntuli's sonnet does not follow the strict physical forms that are followed by Milton, Shakespeare, Spenser or Patriarch, of quatrains and tercets. This is because of tonal characteristics, different metres and poetic foot. The poem is based on nature. Images are skillfully selected to paint rich scenery of winter and springtime. The poet has blended two seasons: The winter which is cold; hills without grass but frost; trees without leaves and singing birds. Springtime is characterized by warmness, green grass and leaves as well as lively singing birds.

\subsection{TM Masuku's sonnet}

Masuku is a poet who wrote a number of sonnets in isiZulu following the Italian and English devices and form. The sonnet, Phambili (Forward), is included in his anthology of poems, Uphondo Lukabhejane (The horns of rhinoceros). Masuku's sonnet has the following pattern: abbaabb a for the octave and cdecde for the sestet. It is a fourteen-line poem which has fixed exposition and turn. Masuku follows rhyme schemes in his poems. The rhyme scheme that shapes his poem hinders the natural rhythmical effects. Masuku is a poet who has a unique style. He uses simple isiZulu to portray his ideas. In most cases, he uses the denotative or literal language rather than figurative language to express his views. This sonnet has a theme of dissatisfaction similar to that of Vilakazi, Wena-ke Uyothini? (What shall you say?) The poet openly complains about the inequality, power and submissiveness which are prevalent in Third World Countries.

\subsection{CT Msimang's sonnet}

Msimang came up with a number of isiZulu sonnets. An example is the sonnet which portrays education through an academic. The sonnet is characterised by an external and internal structure. The example is the following poem: Vilakazi Awusayikubhubha (You will never die, Vilakazi). His sonnet finds its channel in imagery, where the intellectual cognition and perception are combined. The first eight lines humbly request the people to stop crying and heading for the grave, but to wipe away their tears and carefully peruse Vilakazi's writings with the aim of reaching the highest educational level. The first eight lines are collectively known as an octave. An octave develops one thought. It presents the theme or problem of the poem, the thesis. The last six lines resolve the problem by giving direction: if formal education continues, normal life will be attained. The last six lines are collectively called a sestet.

\section{Conclusion}

Few poets have attempted to write sonnets in isiZulu. It appears as if isiZulu poets are not able to adapt the English structural patterns. This is because it is not easy to apply the English metre to 
isiZulu poetry as it is based upon a poetic foot. It is not possible to use all rhyme scheme techniques successfully because isiZulu has words with open syllables; while Western languages have words with closed syllables. As a result, indigenous languages will have to devise some sonnets that will fit their unique structural patterns, because they are tonal languages. It is not easy to adapt all the English styles of writing because of indigenous languages tonal characteristics. Parallelism, refrains and linking are techniques which fit easier among in indigenous languages. The rhythm of African poetry lies in these techniques.

\section{Recommendations}

It is recommended that indigenous languages poets must devise their structurally planned fourteenline narratives that will bear their identity. Their tonal characteristics need emphasis to bring about their unique styles and techniques. The styles of Milton, Shakespeare and Spenser can only be adapted but not copied, due to the English metre, stressed and unstressed syllables, which are dissimilar to those of indigenous languages. The occurrence of beats, which are divided into feet for stressed on accented and unstressed or unaccented need to be blended in indigenous languages for poetic variations, styles and technique. It is evident that the poetic devices, structures and applications vary according to language. An attempt on meter application as rhythmical pattern will bring improvement in writing of poems.

\section{References}

Abrams, M.H. 1985. A Glossary of Literary Terms. Chicago: Holt, Rinehart and Winston, INC. Attenbernd L and Lewis L. 1966. A Handbook for the Study of Poetry. New York: Macmillan Publishers. Babbie, E. \& Mouton J. 2011. The Practice of Social Research. Cape Town: Oxford University. Boulton M. 1953. The Anatomy of Poetry. London: Routlodge and Kegan Paul. Cuddon J.A. 1984. A Dictionary of Literary Terms. Harmondsworth: Penguin Books.

Fletcher, E. and Sceales, W.H.D. 1969. High School English. Cape Town: Maskew Miller Ltd. Ntuli, D.B.Z. 1984. The Poetry of B.W. Vilakazi. Pretoria: J.L. van Schaik Ltd.

Ntuli C.S and Ntuli D.B. 1988. Amehlo KaZulu. Pretoria: Via Afrika (Pty) Ltd. Nyembezi CL.S. 1978. Izibongo Zamakhosi. Petermaritzburg: Shuter and Shooter Publishers. Lever J.W. 1965. The Elizabeth Love Sonnet. London: Methuen Press.

Mabuya L.T.L and Mthiyane E.T.Z. 1986. Amayezi. Johannesburg: Juta Publishers.

Masuku T.M. 1973. Uphondo Lukabhejane. Pretoria: J.L Van Schaik (Pty) Ltd.

Msimang C.T. 1980. Iziziba ZoThukela. Pretoria: Via Afrika (Pty) Ltd.

Msimang C.T. 1990. UNodumehlezi KaMenzi. Pretoria: Bard Publishers.

Scheffler, B 2015. Vistas of Poems. Randhart: Lectio Publishers.

Selden R. 1985. Practical Theory and Reading Literature. Kentucky: Lexinton University Press.

Swanepoel C.F. 1990. African Literature: Approaches and Applications. Pretoria: Haum-Tertiary. 